\title{
The Bongo of the Cherangani Hills
}

\author{
By Mark Stanley Price
}

A beautiful and rarely seen antelope, the bongo, has decreased considerahly in one of its only five known sites in Kenya, the Cherangani Hills. The author was one of a small party who went to the hills to study the bongo among other projects in the summer of 1968.

DESPITE its size and beauty, very few people have seen the bongo Boocercus eurycerus, and virtually no scientific study has been made of it. This lack of information is mostly because it lives in thick montane forest between 6000 and 9000 feet and, unless completely undisturbed, is highly secretive and alert. The bongo's habits have enabled it to be most successful in its rather restricted habitat. It is also cryptically coloured, its white stripes and patches making it invisible when the sun's rays are broken up by the forest canopy.

The bongo belongs to the same sub-family Tragelaphinae of antelopes as the kudu and eland, and is widely distributed in Africa, from Kenya across to the Cameroons in the west. A series of races from West Africa has been described, but these may be of dubious taxonomic validity. However, the Kenyan $B$. e. isaaci because of its distinct coloration and restricted geographic range is certainly a valid group. It is found only in the Aberdare Mountains and Mount Kenya, where large populations are protected in the national parks; in the South-west Mau Forest Reserve: in small numbers in the forest round the summit of the volcano Mount Loldiani; and in the Cherangani Hills. It was in these hills that our expedition spent eight weeks.

The Cherangani Hills rise from the flat farmland 30 miles north-east of Kitale. Our main camp was at Kaibibich which, at nearly 9000 feet, looks down on one side on to a plateau of forest, the 100 square mile KiptaberKapkanya Forest, which, being a national forest, requires a permit for entry. On the other side is a system of deep valleys, some retaining their original gallery forest, with rivers coming down from the central backbone of the hills which rise to nearly 11,000 feet.

Until about six years ago the Cheranganis were legendary for the abundance of bongo, and a most reliable estimate in 1960, based on many observations of herds of known and constant size at a salt-lick, was 300 in this 100 square miles of forest. One of these herds probably visited the lick every morning. We, however, spent several days in a hide at the same site, with salt added to the lick, to be rewarded with one $4 \frac{1}{2}$-minute view of a single male bongo. Extensive walking through the forest revealed that the typical family herds had broken up, for we never saw the spoor of more than one or two bongo together. Moreover, we found no spoor of any young animal, indicating that the destruction of their social structure had put an end to their breeding. Thus it can only be a short time before this population becomes extinct.

In the gallery forest, five miles to the north, the picture was not quite so black. In one small valley four miles long, bongo visited a lick fairly regularly and were observed there, and by walking alone slowly through 
the forest in the early morning or evening we found family groups with young about a year old on several occasions further up the same valley. However, although this may be the last breeding stock in the northern Cheranganis, it probably totals no more than 15 individuals and is restricted to a very small area of forest, the survival of which is precarious.

There are several reasons for the startling decline of bongo in the Cheranganis in the last few years. The local Pokot are pastoralists and do not hunt, but there has been considerable hunting of bongo by the large labour force drawn to the sawmills when these started working a few years ago to the south of the Kiptaber-Kapkanyar Forest. Being employed only seasonally, these men have ample time for using packs of dogs in the forest. Pressure on the bongo from this source is now less, but the forest is still subject to visits every fortnight from certain expatriates to the west.

At the same time the bongo's habitat has been drastically reduced. With the huge population increase in the last few years, the hills are now inhabited right to their summits, despite a harsh climate. Lower down, there has been a corresponding increase in the use of forest glades for grazing, and inevitably this has led to the felling of the forest to provide more open ground. This has been most serious as the felling is following and spreading out from the road to Kaibibich, thereby separating the Kiptaber -Kapkanyar Forest from the gallery forest of the river system. A strip of deforested land with a large human population along the road would effectively create a barrier to the movements of bongo from the gallery forest southwards to the Kiptaber-Kapkanyar Forest.

Another major factor in the bongo's decline has been the reduction in size of the Kiptaber-Kapkanyar National Forest to provide more glades for grazing. This was achieved at the insistence of the local Chief. In addition, the theoretically inviolable national forest has been used freely for grazing cattle. Herds of cattle or their tracks were easily found inside the forest, despite the owners' knowledge that this was illegal and despite the activities of the patrolling forest guards. The cattle are a constant source of disturbance to bongo, and have thus removed any protection which the national forest, through its status, should have conferred.

In view of the decline in the numbers of bongo in the last few years, the expedition made several proposals, which seemed essential for their preservation. Although the Kenya subspecies is in no danger of extinction, there is probably no other place where this animal can be approached safely on foot without the chance of interference from other large game. Moreover, as an area of great beauty with a large and varied fauna and flora, the hills have much to offer the tourist, while their gradual deforestation will destroy their value as an effective water-catchment area for the surrounding farmland, with little material advantage for the local people. For these reasons we have recommended that all cutting of the forest should cease, especially along the road, that the area between the gallery forest and the Kiptaber-Kapkanyar Forest should be given legal protection, and that game scouts be posted in the area to ensure that the national forest is really preserved as a sanctuary. If this can be done, there is a chance that the splinter groups of bongo may re-form into their breeding 
herds. Even though it may be impossible to designate the Cherangani Hills a national park, any measures for conservation must be implemented with the efficiency found in a national park to ensure the survival of bongo there.

\section{Lion $\mathbf{v}$ Buffalo in the Gir}

TPHE 1967 census of the Indian lion in the Gir Forest - its last remain1 ing habitat - showed that numbers had fallen drastically to between 160 and 170 animals. The census was described by Paul Joslin, a PhD student working on the Gir lion population and their behaviour, in ORYX September 1968. One big difficulty in conserving the lions is the large numbers of domestic buffalo allowed to graze in the sanctuary, and now a British PhD student, K. Hodd, working with Paul Joslin, has shown that the buffalo have made about 90 per cent of the sanctuary unsuitable for deer and other wild herbivores that are the lions' natural prey.

During the monsoon the buffalo graze off much of the herbaceous growth, exposing the soil to the heavy rain with inevitable erosion. Many perennial grasses cannot survive the heavy grazing, and the less palatable grasses become dominant. This, combined with the cutting of fodder on the hillsides for the buffaloes, has so reduced the wild herbivores that the lions depend willy nilly for their food on domestic stock - of which there are over 17,000 head. Moreover, because the bulk of the domestic stock are on the periphery of the sanctuary the lions wander outside, where there is no effective protection; more than a sixth of the population is outside the sanctuary area. The government pays compensation for stock killed by lions, but shooting and poisoning of lions still occur; Paul Joslin could point to seven documented cases in 1967. The buffaloes and their herdsmen also reduce the cover the lions need to stalk their prey - the buffaloes by browsing the palatable trees and trampling down the young ones, and the herdsmen by lopping bushes which provide hiding places for predators.

But with management by the Forestry Department the forest is regenerating and not deteriorating into desert as has been reported, and without the domestic buffalo the sanctuary could recover very quickly. After only one monsoon, Mr Hodd's experimental exclosures - fenced-off areas from which all animals were excluded - had made a remarkable recovery and perennial grasses were again abundant. There are indications that the lions may be limiting their own numbers to some extent. Some lionesses make such poor mothers that they leave their young untended to be preyed upon by leopards or shifted by domestic stock, while the lions are generally so aggressive towards the lionesses with cubs that they will flee at the sound of his roar.

Plans are now being considered for an expansion of the research in the Gir Forest, and perhaps the establishment of a research station. The scope for valuable work is immense - not only on the lion population but on other species, on the general ecology of the sanctuary and on the many problems it poses, some of which epitomise conservation problems to be found throughout India. Such a station would also provide a valuable training ground for Indian field workers and conservationists. 